\title{
Sumber Daya Manusia Berdimensi Global
}

\author{
H. Mochammad Edwar Romli \\ Dosen Dpk Kopertis Wilayah II Pada Fakultas Ekonomi Universitas PGRI Palembang
}

\begin{abstract}
ABSTRAK
Sumber daya manusia merupakan faktor yang sangat penting di dalam manajemen karena untuk mencapai tujuan suatu organisasi sangat dibutuhkan adanya sumber daya manusia, termasuk dalam menghadapi globalisasi dewasa ini yang dapat menumbuhkan pasar-pasar atau produk-produk yang baru. Dengan tumbuhnya pasar disertai produk yang baru maka produk yang kita miliki akan bersaing di pasar internasional. Kondisi ini membutuhkan sumber daya manusia yang berkompetensi global supaya produk kita mampu bersaing di dunia internasional. Sehubungan dengan ini tujuan penulisan ini adalah untuk mengetahui (1) Mengapa sumber daya manusia global itu dibutuhkan ?, (2) Hal-hal apa yang dibutuhkan bagi seorang yang akan menjadi sumber daya manusia global, dan (3) Bagaimana pendidikan bagi sumber daya manusia global.
\end{abstract}

Kata Kunci: Sumber daya manusia, berdimensi, global.

\section{A. Pendahuluan}

Setelah mengikuti seminar
nasional kewirausahaan bulan November 2018 yang lalu di Universitas Terbukadi kampusnya di Pondok Cabe, Tangerang Selatan, saya berjumpa dengan keponakan saya yang baru menyelesaikan kuliahnya di bidang bisnis di perguruan tinggi terbaik di Inggris, lalu saya bertanya apa yang banyak dibicarakan orang di bidang sumber daya manusiadi Inggris, dan juga di Amerika, maka dia menjawab di bidang sumber daya manusia yang banyak dibicarakan adalah SDM yang berdimensi global. Sedangkan di bidang pemasaran yang banyak dibicarakan adalah pengaruh kebudayaan terhadap pemasaran.

Memang dewasa in banyak
perusahaan dewasa
mengalami perubahan diantaranya
karena adanya kreativitas dan inovasi
yang menimbulkan produk baru dan
membutuhkan daerah pemasaran

yang baru, adanya persaingan, adanya tuntutan meluaskan pasar, keinginan mendekatkan produk khususnya produk baru dengan calon konsumen, adanya perubahan kondisi social politik disuatu Negara.

Ekspansi suatu perusahaan ke Negara laindapat juga dituntut oleh kebutuhan akan tenaga kerja seperti masuknya perusahaan asing ke Negara RRC yang dikenal tenaga kerjanya murah dan populasi penduduknya terbanyak didunia. Menurut Suwatno dan Donni Juni Priansa (2011:40)faktor sumber daya alam dan calon konsumennya yang banyak dapat pula menjadi factor suatu perusahaan berekspansi ke Negara lain.

Dewasa ini ada kecenderungan perusahaan-perusahaan besar itu berekspansi ke Negara lain karena mereka ingin terhindar dari pencemaran lingkungan di negaranya sendiri, sehingga mereka memindahkan pabriknya ke Negara 
lain walaupun mereka itu tidak bermaksud mencemari Negara lain tersebut. Dengan cara ini pencemaran lingkungan di Negara sendiri dapat dihindarkan atau dicegah.

\section{B. Sistem Ekonomi}

Setiap Negara menganut sistem ekonomi sendiri-sendiri Irma Nilasari dan Sri Wiludjeng (2006-11) mengatakan sistem ekonomi Merupakan sistem dalam mengelola aktivitas ekonomi atau bisnis di suatu Negara seperti dalam mengelola sumber-sumber daya atau faktor-faktor produksiyang dimiliki, termasuk menentukan apa yang akan diproduksi, bagaimana memproduksinya, dan sebagainya. Sistem ekonomi ini dapat terdiri dari sistem ekonomi kapitalisme, sistem ekonomi komunisme, sistem ekonomi fasisme, dan sistem ekonomi campuran. Setiap sistem ekonomi ini mempunyai kelebihan dan kekurangannya masing-masing, yang menjadi ciri karakteristiknya masingmasing.

Sistem ekonomi merupakan salah satu faktor yang berpengaruh terhadap Manajemen SDM, juga dapat menjadi penghambat bagi pengembangan SDM global, Perusahaan-perusahaan di Negara sing sebenarnya lebih senang mendirikan pabriknya di luar negeri atau di Negara lain daripada di negaranya sendiri dengan alasan dekat dengan sumber daya alam atau material yang dibutuhkan,biaya tenaga kerjanya lebih murah sehingga produk yang dihasilkan dapat dijual lebih murah, dan lebih dekat dengan konsumennya, sehingga produk yang mereka hasilkan dapat harganya dapat lebih mudah bersaing dengan produk yang sejenis.
Sistem ekonomi itu berkaitan dengan sistem dalam mengelola sumber-sumber daya (faktor-faktor produksi sehingga dapat mempengaruhi aktivitas di Negara yang bersangkutan dimana SDM itu berekspansi. Seperti sudah dikemukakan di atas, sistem ekonomi itu terdiri atas sebagai berikut:

a.Sistem ekonomi kapitalisme

- Sistem ekonomi ini memberi kesempatan seluas-luasnya kepada pihak swasta untuk menentukan barang atau jasa apa yang akan diproduksi dan bagaimana memproduksinya.

- Dalam sistem ini individu berhak berhak membuat keputusan ekonomi

- Peran pemerintah minim, hanya melindungi masyarakat dari aktivitas bisnis yang merugikan

- Sistem ekonomi ini disebut juga sistem ekonomi pasar bebas.

- Individu berhak membuat keputusan ekonomi.

b.Sistem ekonomi komunisme

- Pemerintah sebagai pembuat seluruh keputusan ekonomi, sehingga disebut juga sebagai sitem ekonomi dengan perencanaan terpusat.

- Seluruh kegiatan bisnis diatur oleh pemerintah pusat.

- Kepemilikan sumber daya berada ditangan pemerintah.

- Masyarakat tidak punya kebebasan dalam aktivitas bisnis

- Umumnya Negara dengan sistem ekonomi komunisme ini jarang 
memiliki catatan yang baik dalam pertumbuhan ekonominya.

\section{c.Sistem ekonomi sosialisme}

- Peran pemerintah dalam bisnis mulai tampak tapi tidak membatasi ruang gerak individu maupun pihak swasta yang ingin terjun ke bisnis.

- Pemerintah memiliki sumber daya ekonomi utama atau vital seperti transportasi, perbankan

- Pemerintah membebani pajak yang tinggi untuk membiayai Negara dan memakmurkan masyaraka tnya

- Pihak swasta mempunyai kebebasan untuk terlibat dalam aktivitas bisnis.

\section{d.Sistem ekonomi fasisme}

- Pemerintah memiliki semua industri

- Keputusan ekonomi dapat dibuat pihak swasta dengan seizin pemerintah.

- Biasanya pemerintah dengan sistem ini dipegang oleh meliterisme.

- Sekarang jarang suatu Negara dengan sistem ini.

\section{e.Sistem ekonomi campuran}

- Pemerintah dapat berfungsi sebagai pengawas aktivitas bisnis yang dijalankan oleh pihak swasta.

- Pemrintah dapat bertindak serbagai pembuat keputusan bisnis untuk menjaga aktivitas bisnis dan ekonomi.

Sistem ekonomi disuatu Negara harus mendapat perhatian bagi sumber daya manusia yang akan berekspansi ke Negara lain atau yang akan bekerja pada perusahaan global atau asing yang ada di dalam negerinya. Sistem ekonomi setiap Negara itu belum tentu sama atau ada perbedaannya, sehingga SDM global harus segera dapat menyesuaikan diri dengan sistem ekonomi di Negara dimana dia akan di tempatkan itu agar tidak terjadi gesekan atau konflik diantara sumber daya atau sumber daya dengan masyarakat di Negara itu.

\section{Pengertian Sumber Daya Manusia}

Edy Sutrisno (2011:3) mengatakan sumber daya manusia (human resources, selanjutnya disingkat SDM) ada yang mengeartikannya sama dengan manpower atau tenaga kerja, bahkan ada yang menyamakannya dengan personalia, kepegawaian, dan sebagainya. Moekijat (2010:2) sumber daya manusia merupakan modal organisasi yang sangat penting.Ini faktor sarana manajemen yang sangat penting, yang merupakan asset yang dapat member nilai tambah bagi organisasi atau perusahaan tersebut. Oleh karena itu sumber daya manusia dalam suatu organisasi harus direncanakan, dikelola dan dimanfaatkan dengan baik agar sumber daya manusia itu mampu memberikan kontribusi bagi organisasi di tempat dia bekerja. Sumber daya manusia itu dapat member kontribusi yan maksimal bagi pencapaian organisasi atau perusahaan bila kesejahteraan kehidupan mereka itu ikut diperhatikan (Danang Sunyoto, 2010,3). Bukan hanya sumber daya manusianya yang ditingkatkan kompetensinya agar kualitasnya sebagai sumber daya manusia itu meningkat, tetapi kesejahteraan mereka harus ditingkatkan. 
Manajemen sumber daya manusia berasal dari kata manajemen. Manajemen diartikan sebagai mengatur (to manage). Di dalam manajemen sumber daya manusia itu yang diatur terutama adalah manusia. Sedangkan di dalam manajemen yang diatur bukan hanya manusia, tetapi juga unsur manajemen atau sarana manajemen yang lain yang mempengaruhi aktivitas manajemen dalam mencapai tujuan (goals) organisasi atau perusahaan seperti material, peralatan, metode kerja, dan pasar,dan uang. Oleh karenaitu sumber daya manusia dapat diartikan sebagai sumber daya yang membicarakan tentang manusia sebagai tenaga kerja, yang di dalam melaksanakan tugas itu mereka harus didukung oleh ketersediaan sana manajemen yang ada.

Dewasa ini bayak perusahaan melakukan ekspansi secara global atau internasional. Sama seperti yang sudah dikemukakan diatas tadi bahwa ekspansi itu dikarenakan untuk lebih mendekatkan usaha perusahaan dengan calon konsumennya atau istilahnya mendekati lokasi pemasaran, mendekatkan diri dengan ketersediaan sumber daya alam maupun tenaga kerja, dan sebagainya, adanya pengaruh dari berdirinya organisasi ekonomi internasional disuatu Negara, dan pengaruh dari globalisasi yang memicu terjadinya perubahan diberbagai bidang termasuk bidang sumber daya manusia yang ditutut harus sudah bersifat global atau internasional. Sumber daya manusia global adalah merupakan sumber daya manusia yang digunakan untuk organisasi yang bersifat interrnasional atau global, sehingga tujuan organisasi itu secara global dapat dicapai. Perusahaan global tentu saja harus menggunakan sumber daya manusia global juga agar perusahaan tersebut dapat berkembang maju.

\section{Globalisasi dan Perubahan}

Globalisasi merupakan suatu perubahan yang menyebabkan adanya keterkaitan atau hubungan antara suatu Negara dengan Negara lain, diantaranya melalui suatu perdagangan atau bisnis, sehingga tidak ada jarak antar Negara. Apa yang terjadi disuatu Negara, dengan mudah dalam waktu singkat dapat diketahui di Negara lain. Globalisasi dapat membentuk persatuan antara Negara-negara di dunia, sehingga Negara-negara itu membentuk satukesatuan yang lebih kokoh dan kuat. Dengan menyatunya beberapa Negara itu akan tercipta dunia baru yang kuat yang dapat mengatur Negara lain yang berada dalam kekuasaannya, sehingga dapat menghancurkan kesetiakawanan diantara Negaranegara yang mengglobal itu.

Globalisasi ekonomi dan perdagangan dunia merupakan kegiatan ekonomi dan perdagangan dunia, sehingga batas antar Negara menjadi kabur karena adanya integrasi antar Negara melalui perdaganan dunia. Globalisasi peronomian mengharuskan dilakukannya penghapusan seluruh batasan dan hambatan terhadap arus modal,investasi,barang dan jasa bahkan tenaga kerja. Globalisasi perekonomian akan membuka peluang pasar bagi produk-produk dalam negeri memasuki pasar luar negeri atau global, sebaliknya produk lokal dapat pula memasuki pasar global. Semua ini membawa dampak pada upaya harus adanya sumber daya manusia yang berdimensi global agar aktivitas perekonomian itu dapat 
berjalan dengaan baik. SDM yang berdimensi global itu harus mempunyai kompertensi global juga, tidak cukup lagi hanya mengandalkan kompetensi lokal saja. Menurut Suwatno dan Donni Juni Priansa (2011:35) kompetensi global yang harus dimiliki seorang ekspatriat adalah sebagai berikut:

\section{a. Keahlian berbahasa}

Setidaknya harus menguasai bahasa Inggris secara lisan tetulis

b. Inteligensi atau kecerdasan sosial

Kecerdasan ini diperlukan agar sebagai SDM global mampu bergaul dan berbaur dengan orang lain ditempat dia ditugaskan, mudah mengambil keputusan, dan mudah menempatkan dirinya di dalam masyarakat ditempat dia bertugas, maupun bergaul dengan sesama sumber daya manusia global.

\section{c. Kemampuan menghadapi konflik}

SDM global harus pula dibekali dengan kemampuan untuk menghadapi konflik atau pertentangan karena konflik dapat saja terjadi dengan karyawan atau antar karyawan, secara horizontal maupun vertical. Oleh karena itu SDM yang akan bertugas secara global atau internasional harus dibekali dengan kemampuan untuk menghadapi konflik yang mungkin dapat terjadi. Kemampuan atau keterampilan menghadapi konflik ini sangat penting diberikan kepada calon sumber daya manusia global. Pada organisasi global atau perusahaan internasional itu, tentu banyak sekali SDM globalnya dengan budaya mereka yang berbeda, sehingga diperlukan kemampuan mengatasi konflik antar budaya yang disesuaikan dengan budayanya masing-masing negara tersebut. Tentu sangat sulit menjadi manajer di perusahaan global yang seperti ini, namun ini tantangan yang harus dihadapi.

\section{d. Fleksibilitas}

Fleksibilitas menyebabkan seseorang itu tidak selalu terikat, sehingga dengan sifat ini seseorang dapat lebih mudah menyesuaikan dirinya dengan lingkungan kerja yang dihadapinya, termasuk dengan karyawan baru atau sesama karyawan di Negara lain.

Dengan adanya sifat fleksibilitas, tidak terikat atau tidak kaku, maka seseorang dapat lebih mudah dalam menyesuaikan diri dengan lingkungan kerjanya, mereka itu lebih mudah berbaur, bergaul.

e. Stabilitas emosi dan adaptabilitas

Stabilitas atau kemantapan emosi sangat diperlukan karena ini menunjukkan kedewasaan dalam berpikir, bertindak atau berbuat, sehingga stabilitas emosi ini akan menunjukkan kemampuan seseorang untuk dapat menyesuaikan diri dengan orang lain atau lingkungan. Apalagi pada perusahaan global, sumber daya manusianya berasal dari berbagai Negara, sehingga menunjukkan adanya keragaman budaya pada sumber daya manusia di perusahaan/organisasi global tersebut, sehingga stabilitas emosi pada setiap SDM globalnya sangat diperlukan supaya mampu menyesuaikan diri atau beradaptasi kepada semua SDM yang memang sudah global itu. Dengan adanya stabilitas emosi, maka penyesuai diri menjadi lebih baik, maka setiap SDM mampu bekerja dengan baik, saling membantu dan menyenangkan 
sehingga diharapkan kinerja mereka menjadi baik.

f. Kemampuan mendengarkan
dengan baik

Setiap SDM, apalagi yang sudah mendapat kedudukan sebagai manajer, harus memiliki kemampuan mendengarkan (listening respon) dengan baik. Dengan kemampuan ini setiap SDM dapat saling mendengarkan dengan baik, sehingga mereka dapat bekerja dengan baik dan saling membantu diantara mereka bila menemui kesulitan

\section{g. Sensitivitas atau kepekaan}

SDM global harus memiliki sifat sensitive atau peka terhadap lingkungan, dalam hal ini termasuk dengan teman-teman yang berada dalam lingkungan kerjanya.Adanya sifat sensitive ini akan menyebabkan mereka mudah merasakan apa yang dirasakan oleh rekan sesama kerjanya, sehingga mereka itu lebih mudah begaul.

\section{h. Perbedaan nilai}

Dalam organisasi atau perusahaan global, perbedaan nilai diantara anggota organisasi itu sudah biasa terjadi karena mereka itu berasal dari latar belakang budaya dan nilai. Tetapi perbedaan nilai itu harus diusahakan dapat dikurangi dengan saling hormat-menghormati agar konflik dapat dihindari.

i. Kemampuan komunikasi nonverbal

mengerti

Komunikasi non verbal merupakan komunikasi tidak menggunakan kata-kata, ucapan, atau berbicara. Tetapi komunikasi ini menggunakan simbol-simbol / tandatanda atau isyarat-isyarat.
Kemampuan komunikasi nonverbal ini harus diketahui diantara para SDM global sehingga mereka mampu berkomunikasi, dan tidak menimbulkan kesalahpahaman atau kesalah pengertian di dalam komunikasi, yang akhirnya dapat menimbulkan konflik diantara SDM tersebut.

\section{j. Kesadaran lintasbudaya}

Setiap negara memiliki budaya dan nilai yang berbeda. Nilai yang dianggap positif atau dibolehkan disuatu tempat, tetapi dianggap negatif atau dilarang di tempat lain. Oleh karena itu setiap SDM global harus mengetahui budaya, nilai atau kebiasaan ditempat dimana dia bekerja agar terjadi kesalahan persepsi yang dapat memacu timbulnya konflik diantara mereka maupun deng warga setempat dimana perusahaan global itu beroperasi. Misalnya kebiasaan memotong hewan yang penduduknya mayoritas muslim dengan non muslim mungkin saja berbeda. Masih bayak lagi contoh yang lain.

Beberapa hal atau faktor yang sudah disebutkan diatas merupakan kompetensi atau kemampuan yang harus dimiliki orang SDM yang berdimensi global. Artinya setiap SDM yang akan menjadi SDM global harus memiliki kompetensi atau kemampuan tersebut diatas. Hal ini sangat diperlukan supaya mereka mampu menjalankan tugasnya sebagai SDM global.

\section{E. Pendidikan Sumber Daya Manusia Global}

Pendidikan merupakan unsure penting dalam menyiapkan sumber daya manusia global. Pendidikan dalam menyiapkan SDM global dapat ditempuhmelalui pendidikan yang ada, 
seperti pendidikan di perguruan tinggi seperti yang ada di Universitas Indonesia, maupun melalui pelatihan yang ada di KementrianLuar Negeri dan Kementrian Transmigrasi dan Tenaga Kerja.

Berdasarkan uraian yang sudah dikemukakan diatas, maka dalam pendidikan untuk meyiapkan sumber daya manusia global itu yang diperlukan adalah:

\section{a) Kemampuan manusia secara verbal}

Untuk menjadi SDM global atau SDM internasional syarat utamanya harus mampu berkomunikasi dalam bahasa asing, khususnya bahasa Inggris baik secara lisan maupun tertulis. Kompetensi dalam bahasa asing ini diperlukan agar tugas-tugas sebagai SDM global dalam menjalin hubungan internasional dan mengenal budaya Negara yang didatangi serta mengenalkan budaya negaranya sendiri didunia internasional dapat mereka lakukan. Apalagi dewasa ini setiap SDM global yang menjabat duta besarsuatu Negara harus mengenalkan produknya ke Negara luar atau asing,sehingga sangat dibutuhkan kemampuan berbahasa asing utamanya bahasa Inggris untuk melakukan tugas-tugas marketing tersebut.

Menurut petugas PBB yang pernah memberikan ceramah kepada pimpinan perguruan tinggi di kota Palembang bertempat di hotel Arya Duta Palembang pada tahun 2015 yang waktu itu saya berkesempatan hadir secara langsung dapat ditarik kesimpulan (1). Minat untuk menjadi SDM global dari kalangan mahasiswa Indonesia sangat kurang sekali,padahal penghasilannya sangat memuaskan. Kurangnya minat ini umumnya terkendala masalah penguasaan Bahasa Inggris. (2). Menurut mereka banyak yang mampu brebahasa asing tetapi yang lebih mampu ternyata lebih banyak. Banyak diantara mereka itu yang lebih menguasai Bahasa Inggris di atas syarat Toefl yang ditentukan, sehingga persaingannya semakin ketat.

b) Stabilitas emosi dan mampu mengatasi konflik

SDM global yang bekerja di Negara asing harus mampu menjaga kestabilan emosinya, tidak boleh terbawa emosi yang dapat menyulut timbulnya konflik antara dirinya dengan penduduk di Negara asing tersebut yang tentunya sangat memalukan Negara yang diwakilinya atau Negara asalnya. Oleh karena itu kestabilan emosinya harus dapat dijaga agar tidak terjadi konflik. Karena itu mereka juga harus mengetahui dan menguasai bagaimana cara-cara mengatasi konflik.

c) Mencegah budaya perbedaan nilai

Perbedaan nilai antara SDM global dengan penduduk Negara yang didatangi sangat mungkin untuk terjadi karena mereka berasal dari latar belakang dan budaya yang berbeda. Oleh karena itu diperlukan sikap saling hormat menghormati dan tidak mencampuri urusan dalam negeri orang lain.
d) Mengenal sistem ekonomi di negara lain

Tugas SDM globaljuga harus mampu memasarkan produk yang dihasilkan tempat dia berasal Semua SDM global harus dapat membantu negaranya menjalankan fungsi marketing dalam upaya memasarkan produk yang dihasilkan negaranya di 
Negara asing tempat dia bekerja itu. Oleh karena itu SDM global harus mengenal sistem ekonomi yang dianut negaranya dan Negara asing di tempat dia bekerja. Hal ini penting supaya tidak bertentangan dengan sistem ekonomi yang dianut masing-masing Negara sehingga tugas-tugas perekonomian dapat dijalankan dengan lancar tanpa, ada penolakan atau hambatan

\section{F. Kesimpulan}

Dari pembahasan yang telah dilakukan dapat ditarik kesimpulan sebagai berikut :

a) Sumberdaya manusia global dibutuhkan karena adanya pengaruh globalisasi ekonomi yang menyebabkan terjadinyakompetisi dalam penjualan produk yang masuk ke suatu Negara, juga karena adanya perluasan aktivitas oganisasiglobal baik dalam bentuk organisasi bisnis maupun politik dibawah organisasi PBB maupun organisasi lainya yang sifatnya lebih mengglobal, dan juga adanya kebutuhan dari suatu Negara untuk memasarkan produk yang dihasilkannya di Negara lain agar produk itu dikenal calon konsumen, dibeli konsumen sehingga aktivitas bisnisny a lebih meluas secara global.

b) Beberapa hal yang dibutuhkan bagi orang yang akan menjadi Sdm global adalah:

- Menguasai bahasa asing terutama bahasa Inggris secara lisan dan tertulis

- Mengenal budaya negaranya sendiri maupun budaya Negara asing tempat SdDM gitu akan bekerja

- Mengenal sistem ekonomi Negara sendiri, sistem ekonomi yang ada maupun sistem ekonomi yang berlaku di Negara asing tersebut.

- Mengetahui penyebab konflik dan bagaimana cara mengatasi konflik, mencegah terjadinya konflik, dan bagaimana cara mengatasi konflik.

c) Pendidikan bagi SDM global itu dapat dilakukan melalui perguruan tinggi yang sengaja menyiap kan lulusan yang berwawasan global sehingga lulusannya mampu bekerja secara global, tetapi dapat juga dilakukan melalui institusi tertentu yang sengaja menyiapkan lulusannya untuk mampu bekerja secara global seperti yang dilaksanakan oleh Departemen Tenaga Kerja dan Transmigrasi.

d) Kebutuhan Sdm global sebenarnya sangat banyak, karena itu Sdm global perlu disiapkan dengan matang baik pengetahuan maupun ketrampilannya, terutama yang dibutuhkan untuk tingkat global, kemudian mereka itu perlu diotawarkan kepada pencari kerja tingkat global.

\section{G. Saran}

a) Kesempatan untuk menjadi SDM global sangat besar, karena itu bagi yang berminat harus dapat menyiapkan diri dengan sebaik mungkin, terutama dalam kompetensi berbahasa asing secara lisan dan tertulis. 
b) Kebutuhan SDM global sebenarnya sangat banyak, tetapi kesiapan mengadakannya masih terbatas. Oleh karena itu melalui lembaga pendidikan dan pelatihan yang ada

c) Bagi yang akan menjadi SDM global harus benar-benar mengenal budaya negaranya sendiri maupun budaya Negara asing ditempat dia akan bekerja, sehingga tidak terjadi konflik dirinya dengan penduduk di Negara asing tersebut.

d) Disarankan agar mereka yang akan menjadi Sdm global agar mulai melatih diri dengan berpikir dan bertindak secara global.

e) Perguruan tinggi harus berusaha menyiapkan lulusannya untuk mampu bekerja secara global atau menjadi SDM global agar tidak tertinggal dengan perguruan tinggi lain. Oleh karena itu persiapannya harus sungguhsungguh dan tidak asal-asalan saja.

f) Kalau memungkinkan pihak perguruan tinggi atau pemerintah kiranya dapat menawarkan tenaga kerja atau SDM yang berkemampuan global itu ke lembaga kerja yang ada supaya mereka dapat ditempatkan di Negara lain. g) Bagi mereka yang akan mengikuti pendidikan secara global agar kelak dapat bekerja secara global, maka mereka yang mengikuti pendidikan itu harus yang benar-benar mampu secara intelektualitasnya supaya mereka mampu berprerstasi dalam menempuh pendidikan itu dan nanti ilmu pengetahuan serta ketrampilan yang telah diperolehnya dapat disumbangkan bagi negaranya maupun di tempat dia bekerja.

\section{DAFTAR PUSTAKA}

Edy Sutrisno, 2009, Manajemen Sumber Daya Manusia, Prenada Media, Jakarta.

Danang Sunyoto, 2012, Manajemen Sumber Daya Manusia, 2012, CAPS, Jakarta.

Moekijat, 2010, Manajemen Sumber daya Manusia, Mandar Madju, Bandung.

Nilasari dan Sri wiludjeng, 2006, Pengantar Bisnis, Alfabeta Bandung

Suwatno dan Donni Juni Priansa, 2011, Manejemen sumber Daya Manusia, Alfabeta, Bandung. 